\title{
CLIMATE, URBANIZATION, AND CONFLICT: THE EFFECTS OF WEATHER SHOCKS AND FLOODS ON URBAN SOCIAL DISORDER
}

David Castells-Quintana and Thomas K.J. McDermott

NO. 588

July 2019
ADB ECONOMICS WORKING PAPER SERIES 


\section{Climate, Urbanization, and Conflict: The Effects of Weather Shocks and Floods on Urban Social Disorder}

David Castells-Quintana and Thomas K.J. McDermott

No. 588 | July 2019
David Castells-Quintana (david.castells.quintana@uab.cat) is a post-doctoral researcher at the Applied Economics Department of the Universidad Autonoma de Barcelona. Thomas K.J. McDermott (thomas.mcdermott@nuigalway.ie) is a Government of Ireland Research Fellow at the SocioEconomic Marine Research Unit (SEMRU) of the National University of Ireland Galway.

This paper was prepared as background material for the Asian Development Outlook 2019 theme chapter on "Strengthening Disaster Resilience." We are very grateful to Maria del Pilar Lopez-Uribe, Joshua Hallwright, and participants at the Asian Development Bank workshop on Disasters and Development held in Manila in December 2018 for helpful discussion and comments. McDermott gratefully acknowledges the support of the Irish Research Council. 
(C) 2019 Asian Development Bank 6 ADB Avenue, Mandaluyong City, 1550 Metro Manila, Philippines

Tel +632632 4444; Fax +6326362444

www.adb.org

Some rights reserved. Published in 2019.

ISSN 2313-6537 (print), 2313-6545 (electronic)

Publication Stock No. WPS190254-2

DOI: http://dx.doi.org/10.22617/WPS190254-2

The views expressed in this publication are those of the authors and do not necessarily reflect the views and policies of the Asian Development Bank (ADB) or its Board of Governors or the governments they represent.

ADB does not guarantee the accuracy of the data included in this publication and accepts no responsibility for any consequence of their use. The mention of specific companies or products of manufacturers does not imply that they are endorsed or recommended by ADB in preference to others of a similar nature that are not mentioned.

By making any designation of or reference to a particular territory or geographic area, or by using the term "country" in this document, $A D B$ does not intend to make any judgments as to the legal or other status of any territory or area.

This work is available under the Creative Commons Attribution 3.0 IGO license (CC BY 3.0 IGO)

https://creativecommons.org/licenses/by/3.o/igo/. By using the content of this publication, you agree to be bound by the terms of this license. For attribution, translations, adaptations, and permissions, please read the provisions and terms of use at https://www.adb.org/terms-use\#openaccess.

This CC license does not apply to non-ADB copyright materials in this publication. If the material is attributed to another source, please contact the copyright owner or publisher of that source for permission to reproduce it. $\mathrm{ADB}$ cannot be held liable for any claims that arise as a result of your use of the material.

Please contact pubsmarketing@adb.org if you have questions or comments with respect to content, or if you wish to obtain copyright permission for your intended use that does not fall within these terms, or for permission to use the ADB logo.

Corrigenda to ADB publications may be found at http://www.adb.org/publications/corrigenda.

Note:

In this publication, “\$” refers to United States dollars.

The ADB Economics Working Paper Series presents data, information, and/or findings from ongoing research and studies to encourage exchange of ideas and to elicit comment and feedback about development issues in Asia and the Pacific. Since papers in this series are intended for quick and easy dissemination, the content may or may not be fully edited and may later be modified for final publication. 


\section{CONTENTS}

TABLES AND FIGURES Iv

ABSTRACT V v v v v

ABBREVIATIONS vi

$\begin{array}{lll}\text { I. INTRODUCTION } & 1\end{array}$

II. CLIMATE, URBANIZATION AND CONFLICT: A REVIEW OF THE LITERATURE 3

A. Weather Shocks and Conflict $\quad 3$

B. Weather Shocks, Urbanization, and City Growth 4

C. Migration to Cities, Urbanization, and Conflict 4

III. DATA AND DESCRIPTIVE ANALYSIS

A. Data Sources and Main Variables 5

B. $\quad$ Descriptive Analysis and Stylized Facts $\quad 7$

IV. EMPIRICAL ANALYSIS

A. Estimation Strategy

B. Results 13

$\begin{array}{lll}\text { V. } & \text { CONCLUSIONS, DISCUSSION, AND NEXT STEPS } & 18\end{array}$

$\begin{array}{ll}\text { REFERENCES } & 21\end{array}$ 


\section{TABLES AND FIGURES}

\section{TABLES}

$1 \quad$ Summary Statistics $\quad 7$

2 Effect of Weather Shocks on City Population 13

3 Effect of Weather Shocks on Urbanization Rate 14

4 Effect of Floods on City Population 16

$5 \quad$ Effect of Floods on Urban Conflict Events, Intensive Margin 17

6 Effect of Floods on Urban Conflict Events, Extensive Margin 17

7 Effect of City Population on Urban Conflict Events, Intensive, and Extensive Margins 18

\section{FIGURES}

$1 \quad$ Evolution of Main Variables 8

2 Association between Main Variables 10 


\begin{abstract}
In this paper, we test the effect of weather shocks and floods on urban social disorder for a panel of large cities in developing countries. We focus on a particular mechanism, namely the displacement of population into (large) cities. We test this hypothesis using a novel dataset on floods-distinguishing those that affected large cities directly from those that occurred outside of our sample of large cities. Floods are found to be associated with faster growth of the population in the city, and in turn with a higher likelihood (and frequency) of urban social disorder events. Our evidence suggests that the effects of floods on urban social disorder occur (mainly) through the displacement of population, and the "push" of people into large cities. Our findings have important implications for evaluating future climate change, as well as for policies regarding adaptation to climate change and disaster resilience.
\end{abstract}

Keywords: climate change, conflict, floods, migration, rainfall, social disorder, urbanization

JEL codes: D90, I30, J60, O10, Q00, Q01, Q50 


\section{INTRODUCTION}

In this paper, we test the effect of weather shocks on urban social disorder, with a particular focus on the role of floods that occur outside of large cities, in "pushing" population into these cites, potentially resulting in social tensions and conflict in urban areas. Disasters related to natural hazards and weather shocks regularly cause displacement of population from rural to urban areas (see, for example, Barrios, Bertinelli, and Strobl 2006; Marchiori, Maystadt, and Schumacher 2012; Henderson, Storeygard, and Deichmann 2014). Floods, in particular, displace large numbers of people every year. In the past 30 years, they have displaced 650 million people worldwide, according to data from the Dartmouth Flood Observatory (Brakenridge 1985-present). While floods impact on all world regions, the magnitude of effects is particularly pronounced for countries in developing Asia (see section III.B, Figure 1). The risk of flooding is also anticipated to increase rapidly in the coming decades, due to a combination of increasing exposure-due to ongoing socioeconomic trends (including population and economic growth, and continuing urbanization)-and increasing hazard because of climate change effects on rainfall patterns and continuing sea level rise (Hallegatte et al. 2013, Jongman et al. 2014).

This displacement of people has potentially important economic and social consequences. A changing configuration of the spatial distribution of population and economic activity has direct effects on economic performance and development, as now widely acknowledged by the literature (Henderson 2003, Brülhart and Sbergami 2009, Castells-Quintana 2017). Migrations-both temporary and permanent-have also long been used as risk-coping mechanisms in the face of weather shocks, disasters, and other income or productivity shocks (Gray and Mueller 2012; Henderson, Storeygard, and Deichmann 2017).

At the same time, the displacement of people may create social tensions where resources are scarce and overcrowding occurs, or when there is excessive demand for public services (CastellsQuintana, Lopez-Uribe, and McDermott 2018). As an example, Collier, Conway, and Venables (2008) point to problems with access to land for newly arrived rural-to-urban migrants. Disorderly or reactive migration in response to weather shocks may lead to disruptions in economic activity and even social disorder (see Waldinger 2016, and citations therein, for further discussion).

While there is a growing literature on urbanization and conflict (for example, Buhaug and Urdal 2013, Ostby 2016), to date the findings in this literature have been mixed. In this paper, we test the effect of flooding that occurred outside of our sample of large cities (an exogenous source of variation in city population) on urban disorder in major cities across the developing world. Arguably, not all urbanization is equal. Urbanization is mainly determined by rural-urban migration and natural population growth. Traditionally, rural-urban migration has been associated with a process of structural change, higher productivity growth, and economic development. However, nowadays in many poor countries, urbanization is not necessarily associated with economic development. Rural-urban migration in many poor countries seems more the outcome of "push" rather than "pull" factors: deteriorating agricultural conditions worsened by climate change, high volatility in agricultural prices, disasters, and even violent conflict in rural areas. The "push" of people into urban areas does not necessarily increase productivity (see, for instance, Lipton 1977; Bates 1981; Bairoch 1988; Barrios, Bertinelli, and Strobl 2006).

Furthermore, a particular methodological issue with this literature is to identify a causal relationship between variation in urban population and urban disorder. We propose to use weather shocks, and in particular flood events that occur outside of major cities, as an exogenous push factor 
driving rural-urban migration, and potentially leading to social disorder in adjacent urban areas. Weather shocks and floods can impact conflict directly by increasing the competition for limited resources, but also by altering other socioeconomic dynamics. One of these is the concentration of population in urban areas. Developing countries experience today a very rapid process of urbanization. In many cases, this translates to a growth of urban agglomerations (cities) that can now reach 10, 20, or even 30 million inhabitants. Disasters related to natural hazards and changes in climatic conditions increasingly represent an important "push" factor. As more people get "pushed" to (large) cities, unplanned urbanization and city growth bring important challenges for sustainable development, straining basic urban services like sanitation, electricity, and transportation, as well as the job market (Collier, Conway, and Venables 2008; Castells-Quintana, Lopez-Uribe, and McDermott 2018). These challenges could fuel conflict in urban areas.

The aim of this paper is to analyze the potential effects that weather shocks, in particular floods, can have on patterns of economic development through the displacement of population from rural to urban areas. In particular, we aim to test the effects of rural-urban migration on social disorder within cities, with weather shocks as the impulse for this population movement. We do this by analyzing data for more than 138 (large) cities in 138 countries (one city per country), from 1960 to 2015.

Our paper relates to at least three strands in the literature: i) papers studying the connection between weather shocks and conflict, ii) papers studying the connection between weather shocks and urbanization, and iii) papers focusing on conflict in urban areas (see section II for a brief overview of this literature). While the literature suggests a potential connection between weather shocks, urbanization, and conflict in urban areas, to the best of our knowledge, there is no paper empirically testing this connection in a global panel of countries and/or cities. Our paper aims to fill this gap.

In line with previous literature, we find that rainfall anomalies affect the rate of urbanization in developing countries. However, we also identify diverse effects across two different world regions; in sub-Saharan Africa (SSA), lower-than-expected rainfall is associated with more urbanization, while in Asia, higher than expected rainfall leads to higher growth of (large) cities. We explain this latter finding with respect to the effects of flooding in Asia. We test this hypothesis explicitly using a novel dataset on floods-distinguishing those that affected large cities directly from those that occurred outside of our sample of large cities. The latter events are strong predictors of population in the city, and in turn of the likelihood (and frequency) of urban social disorder events. Our evidence suggests a positive correlation between floods and urban social disorder that occurs (mainly) through the displacement of population, and the "push" into large cities. Our findings have important implications for evaluating future climate change, as well as for policies regarding climate and disaster resilience.

The remainder of our paper proceeds as follows. In section II, we briefly review the three strands of related literature already mentioned. In section III, we present our data, providing a descriptive analysis of the coevolution of weather shocks and floods, urbanization and city growth, and social conflict in urban areas. Section IV performs some econometric analysis and presents our main results. Finally, section $V$ concludes, highlighting policy implications from our results and avenues for further research. 


\section{CLIMATE, URBANIZATION AND CONFLICT: A REVIEW OF THE LITERATURE}

\section{A. Weather Shocks and Conflict}

Recent decades have seen an increase in the interest in the relationship between natural resources and conflict. A body of literature argues that the abundance of natural resources, in particular minerals and oil, is positively correlated to violence and conflict. The abundance and easy access to these resources can be used to fund rebel organizations and can lead to frictions over their allocations. At the same time, the state dependence on these commodities can weaken state capacity (Hendrix 2010). Other authors have supported the idea that it is the scarcity of vital resources, like water and food, that can lead to conflict (see below). In this context, the scarcity of resources can generate grievances and fuel uprisings and disorders over distribution.

Several researchers have tried to test the causal relationship between income, natural resources, disasters, and social disorder (or conflict). They have relied on the consensus that low levels of income are correlated with high levels of uprisings, protests and riots, and look at land and water resources to determine the link between scarcity and this type of conflict. As income is endogenous to conflict, they have used rainfall as a source of exogenous variation of income. For example, Miguel, Satyanath, and Sergenti (2004) use rainfall growth as an instrument for gross domestic product (GDP) growth in SSA and find that lower economic growth increases the probability of conflict, in particular civil war. Bohlken and Sergenti (2010) run a similar analysis for India, instrumenting for state-level GDP with rainfall. They also find that low rainfall growth increases the number of riots that a state experiences in a given year. The idea behind using rainfall as a plausible candidate instrument is that low levels of rainfall result in crop failure, thereby depressing rural income. However, the critical assumption underlying the use of rainfall as an instrumental variable is that rainfall affects conflict only through its impact on income.

Other authors have found a weaker relationship. Couttenier and Soubeyran (2014) argue that the relationship between rainfall and conflict (i.e., civil war) is driven by aggregate shocks, in particular global climate shocks. Using a country-specific drought measure and a difference in difference specification, the authors find a weaker relationship between droughts and civil war. Ciccone (2011) revisits Miguel, Satyanath, and Sergenti's (2004) analysis of civil war in SSA and shows that there is actually a positive correlation between twice-lagged rainfall levels and current conflict. This author develops this point later (Ciccone 2013) and looks at the effect of transitory shocks on conflict risk to test whether income shocks lower the opportunity cost of participating in violence, and finds again that negative income shocks lower the risk of civil conflict. In contrast with these two groups of authors, Hendrix and Salehyan (2012) demonstrate the existence of a curvilinear relationship between rainfall and social conflict for African countries: very high and very low rainfall years increase the likelihood of all types of political and social conflict.

In terms of the mechanisms that relate weather shocks, and in particular rainfall deviations, with conflict, the literature has suggested at least five different mechanisms. ${ }^{1}$ A first body of literature focuses on access to water. During rainfall shortages water stores decline, and consumers may come into conflict within their own society over access to wells and riverbeds (Kahl 2006) or over water rights and access

\footnotetext{
The literature emphasizes the importance of extreme events, since deviations from normal rainfall disrupt the expectations societies develop about normal rainfall patterns, and accordingly, their plans for crops and coping strategies (Reardon and Taylor 1996).
} 
(Eriksen and Lind 2009). A second group of authors focuses on the effect of droughts and floods on food prices, leading to disputes between rural producers and urban consumers. Alexandratos (2008), for example, has shown that the rising price of staple crops in 2008 and 2011 led to massive protests and riots when urban consumers started to demand relief from food price inflation. A third mechanism relates to the effect on government revenues through a reduction of the tax base or an increase in the demand for services and assistance to respond to weather shocks. This is particularly true in countries where agriculture and other water-intensive sectors are central for the national economy, as is the case in many African countries. As Benson and Clay (1998) have shown for African economies, extreme weather events have had a particularly pronounced effect on public finances. A fourth mechanism relates to the effects on overall growth (Miguel, Satyanath, and Sergenti 2004; Barrios, Bertinelli, and Strobl 2010; Jensen and Gleditsch 2009). Rainfall anomalies can lead to displacement or crop failure, which at the same time affect economic productivity. General economic discontent may in turn lead to public disorder and conflict. In what we have identified as a fifth mechanism, rainfall deviations may also affect livelihoods, forcing many to migrate to urban areas in search of better opportunities. Migration to cities increases the supply of labor, leading to more intense competition over jobs. Similarly, more migrants in cities affect the demand for housing and other basic services such as sanitation, electricity, police protection, and roads (Neuwirth 2005). Our paper focuses on this last mechanism, which to the best of our knowledge, has not been explicitly tested in the literature to date.

\section{B. Weather Shocks, Urbanization, and City Growth}

The literature on climate change and urbanization has focused on the effect of rainfall on urbanization, mainly in Africa. For example, Barrios, Bertinelli, and Strobl (2006) estimate that shortages in rainfall have acted to increase rates of urbanization on SSA countries, but they have not found evidence of a similar effect for the rest of the developing world. Moreover, they find that this effect has been reinforced after the colonial independence of SSA, which in many cases has been associated with legislation that lifted the prohibition of the free internal movement of native Africans. Henderson, Storeygard, and Deichmann (2014; 2017) confirm the strong link between weather shocks-in particular, rainfall-and urbanization and city growth. More severe and persistent climate changes, measured with respect to rainfall, will likely increase the challenges faced by farmers and further accelerate migration to cities. This occurs primarily in arid countries in SSA. By lowering farm incomes, shortages in rainfall encourages migration to nearby cities, while wetter conditions slow it. Similarly, Bruckner (2012) uses rainfall as an instrument for agricultural GDP share in Africa and finds that a decrease in this share leads to increased urbanization.

\section{Migration to Cities, Urbanization, and Conflict}

The literature that links migration and conflict has focused mainly on rural-urban migration as a potential driver of grievances and opportunities for violent mobilization. The explanations that the literature has used include relative deprivation and radicalization of migrants, reduced opportunity costs, enhanced social communication, and ethnic frictions. The influx of rural-urban migrants tends not to be accommodated by public or private sectors, and migrants are likely to experience rising relative deprivation, which in turn increases the likelihood of their engaging in social disorder (Gizewski and Homer-Dixon 1995). Migrants may also have problems adjusting to life in the cities, in particular, because of disruption to their old customs and habits. As a result, migrants may tend to be more easily recruited into radical movements (Gizewski and Homer-Dixon 1995). In urban environments, there is also a more intense competition for access to services and jobs among migrants and local urbanites (Reuveny 2007). Cities can also be ethnically and religiously diverse, and this mixing may represent a further destabilizing factor (Beall, Guha-Khasnobis, and Kanbur 2010). 
Despite the several theoretical reasons to expect a link between rapid urbanization (and city growth) and conflict in urban areas, there is a relatively limited literature that has empirically tested the link between the two. Buhaug and Urdal (2013) find no support for the "urbanization bomb"-the idea that urban population growth should lead to an increase in political violence. Ostby (2016) investigates the relationship between migration into cities and political violence with city-level data in Africa and Asia, and finds that the movement of rural people into the cities creates social disorder through mechanisms such as poverty, unequal educational opportunities, and the socioeconomic marginalization of rural-urban migrants. Our analysis is in line with research that argues there may be a link between climate, urbanization, and (urban) conflict. In this article, we examine the effects of flooding on social disorders in urban areas, testing more explicitly city growth as the mechanism between these links. In addition, while most of the literature has focused on one region, mainly Africa, or short periods, we test our hypothesis over a period of 50 years for a large world sample. This allows us to study differentiated effects across world regions (mainly differences between Africa and Asia). Our analysis is also in line with the work of Bhavnani and Lacina (2015) in India, who test the causal effect of migration on social disorder, using abnormal rainfall in migrant-sending states as an instrument for migration, and conclude that migration, on average, leads to rioting in the host area.

\section{DATA AND DESCRIPTIVE ANALYSIS}

To study the potential effects of weather shocks on urbanization and city growth, and through these on social disorder in urban areas, we build a large dataset considering 138 countries over the 19602015 period. Our dataset includes several variables for our three key dimensions, namely weather shocks, urbanization and city growth, and social disorder in urban areas. For weather shocks, we consider rainfall anomalies, average temperatures (constructed from monthly gridded data), and the number of people displaced by floods. For urbanization and city growth, we consider urbanization rates and population (in logs) in largest cities. For social disorder in urban areas, we consider different measures. Below we explain our key variables and sources.

\section{A. Data Sources and Main Variables}

\section{Weather Shocks Data}

Our variables to capture weather shocks come from two main sources. Historical weather data, including temperature and rainfall observations, are derived from monthly global gridded data, which have been aggregated to country means. ${ }^{2}$ Our main measure of rainfall, rain_anom, captures annual deviations in rainfall for a particular country, relative to the variability of year-to-year rainfall for that country (as used in, for example, Barrios, Bertinelli, and Strobl 2006 and Hendrix and Salehyan 2012), and is defined as Rain_anom ${ }_{i t}=\left(\right.$ ann_rain $_{i t}-$ mean_rain $\left._{i}\right) /$ sd_rain $_{i} \cdot{ }^{3}$ We also include observations of annual average temperatures from the same source.

2 The country-level datasets that we use were obtained from the World Bank's Climate Change Knowledge Portal at http://sdwebx.worldbank.org/climateportal/index.cfm?page=downscaled_data_download\&menu=historical (accessed 7 November 2018). These data are derived from the University of East Anglia's Climate Research Unit time series dataset of high resolution gridded monthly climatic observations (see Harris et al. 2014).

3 The rain_anom variable is standardized, such that the mean in our sample is close to 0 , the standard deviation is approximately 0.5 , and the range of values in the sample is from roughly -2 to +2 (see Table 1 , which includes summary statistics for our main variables). 
Our data on the number of people displaced by floods come from the Dartmouth Flood Observatory (DFO) archive (Brakenridge 1985-present). The DFO database includes information by event on the location, timing, duration, damage, and the number of people killed and displaced, for thousands of flood events worldwide from 1985-2015, compiled from media estimates and government reports. Particularly useful for our purposes are a set of shapefiles that define the areas affected by each flood event in the archive. While these shapefiles often cover fairly broad areas (these are not inundation maps), for the purposes of our city-level analysis, they allow us to distinguish floods that have impacted directly on the cities in our data from those that have affected other areas within the same country. ${ }^{4}$ This is particularly useful for our purposes. Many flood events impact directly on large cities, displacing people already living in cities. These events would not therefore be expected to increase the population of those cities. By contrast, flood events occurring outside of major cities, and displacing population, may cause (some of) those displaced to move to the city. Using geographic information system software, we overlap the flood shapefiles obtained from DFO, with coordinates of the cities in our data (one city per country), to distinguish flood events that overlap with the city from those that affect other areas within the same country. Based on this categorization, we are able to construct our main flood variable, which is the sum of the number of people displaced by flood events occurring in country $i$ in period $t$, which did not overlap with the largest city in that country. ${ }^{5}$

\section{Urban Data}

For urbanization and city growth we focus on two sets of variables. On the one hand, we use urbanization rates, defined as population living in urban areas as a percentage of total population. On the other hand, we use population in the largest city. The focus on the largest cities rests on the fact that the pattern of urbanization in many developing countries shows a high degree of urban concentration, with one or few cities of disproportionate size. For urban population, we use data from the United Nations World Urbanization Prospects, which includes observations of city population every 5 years from 1950 to 2015 (United Nations 1950-2050). In line with the urban economics literature, cities are considered not as administrative units but as functional urban areas. This means that we consider population in the whole urban agglomeration, which is not only more appropriate to capture the reality of urban residents, but also make the comparability across cities in different countries easier.

\section{Urban Conflict Data}

For conflict in urban areas, we use data from the Urban Social Disorder (USD) dataset. ${ }^{6}$ This dataset gives information on the number of disorder events in urban areas, including demonstrations, riots, and armed conflict (battles or terrorist events), a proxy of the intensity by giving an estimate of the number

4 As per the DFO website, Archive Notes: "Polygons representing the areas affected by flooding are drawn in a geographic information system program based upon information acquired from news sources. Note: These are not actual flooded areas but rather the extent of geographic regions affected by flooding." (accessed November 2018).

5 The definition of "displaced," as used in the DFO archive is as follows: "Number Displaced-This number is sometimes the total number of people left homeless after the incident, and sometimes it is the number evacuated during the flood. News reports will often mention a number of people that are 'affected,' but we do not use this. If the only information is the number of houses destroyed or damaged, then DFO assumes that 4 people live in each house. If the news report only mentions that 'thousands were evacuated,' the number is estimated at 3000. If the news reports mention that 'more than 10,000' were displaced then the DFO number is 11,000 (number plus 10\%). If the only information is the number of families left homeless, then DFO assumes that there are 4 people in each family." (DFO website, Archive Notes at http://floodobservatory.colorado.edu/Archives/ArchiveNotes.html, accessed November 2018).

6 Available from https://www.prio.org/Data/Armed-Conflict/Urban-Social-Disorder/ (accessed November 2018). 
of people involved in each incident and the number of fatalities (if any). We code this information, for integration with our climate and urban data, by counting the number of events per city-period (summing over 5-year intervals from 1960 to 2015), taking one city per country (as discussed above)as our measure of the intensive margin of urban events. We also create a binary indicator for whether a given city experienced any disorder events in a 5-year period-our measure of the extensive margin of urban disorder. Both measures are generated for all events, and separately for events that involved fatalities and those that did not involve any fatalities, according to the USD data.

\section{B. Descriptive Analysis and Stylized Facts}

Before performing econometric analysis, we can look at our data for our three key dimensions (weather shocks, urbanization and city growth, and conflict in urban areas). Table 1 presents summary statistics for our main variables for our world sample. Figures la-1f present the evolution of rainfall, floods, urban growth, and conflict in urban areas. The figures show the average across countries for our world sample, for developing Asian countries only, and for SSA countries only.

Table 1: Summary Statistics

\begin{tabular}{|c|c|c|c|c|c|}
\hline Variable & Obs. & Mean & Std. Dev. & Min & Max \\
\hline Rainfall anomalies & 1,781 & 0.035 & 0.547 & -2.257 & 2.111 \\
\hline Annual rainfall & 1,781 & $1,038.10$ & 760.14 & 27.35 & $3,331.46$ \\
\hline Annual temperature & 1,781 & 18.55 & 8.12 & -7.38 & 29.14 \\
\hline $\begin{array}{l}\text { Number displaced by floods } \\
\text { (total) }\end{array}$ & 834 & 744,473 & $5,235,825$ & 0 & $9.91 E+07$ \\
\hline $\begin{array}{l}\text { Number displaced by floods } \\
\text { (no city) }\end{array}$ & 834 & 481,368 & $3,194,748$ & 0 & $4.87 E+07$ \\
\hline $\begin{array}{l}\text { Number displaced by floods } \\
\text { (city) }\end{array}$ & 834 & 263,105 & $2,430,352$ & 0 & $5.50 \mathrm{E}+07$ \\
\hline Urbanization rate & 1,617 & 48.77 & 24.85 & 2.08 & 100 \\
\hline City population & 2,114 & $2,286.71$ & $3,887.20$ & 2.70 & $38,001.02$ \\
\hline Urban social disorder (all events) & 946 & 8.46 & 14.39 & 0 & 208 \\
\hline Fatal disorder events & 946 & 3.71 & 10.04 & 0 & 176 \\
\hline Nonfatal disorder events & 946 & 4.74 & 6.75 & 0 & 52 \\
\hline
\end{tabular}

Min = minimum, Max = maximum, Obs. = observations, Std. Dev. = standard deviation.

Notes: Rainfall anomalies are measured as annual deviations from rainfall relative to the variability of year-to-year rainfall; annual rainfall is measured in millimeters; annual temperature is measured in Celsius degrees; numbers displaced by floods measured in number of people; we define separately floods that did not overlap with the largest city in each country (no city), and those that did overlap the largest city (city); urbanization rate is defined as the population living in urban areas as a percentage of total population; city population is the population in the largest city in thousands; urban social disorder is measured in number of events observed per city; we define separately a measure that counts the number of events where at least one fatality was recorded, and the count of events where no fatalities were recorded. The data are observed for the period 1960-2015, with the exception of floods, which are observed for the period 1985-2015.

Source: Authors' calculations. 


\section{Figure 1: Evolution of Main Variables}

(a) Annual rainfall

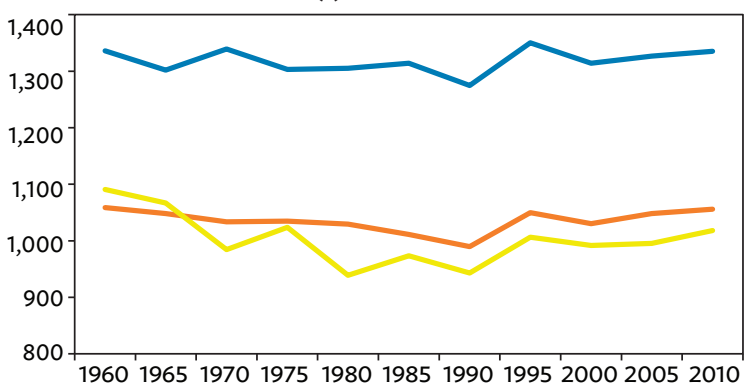

(c) People displaced by floods

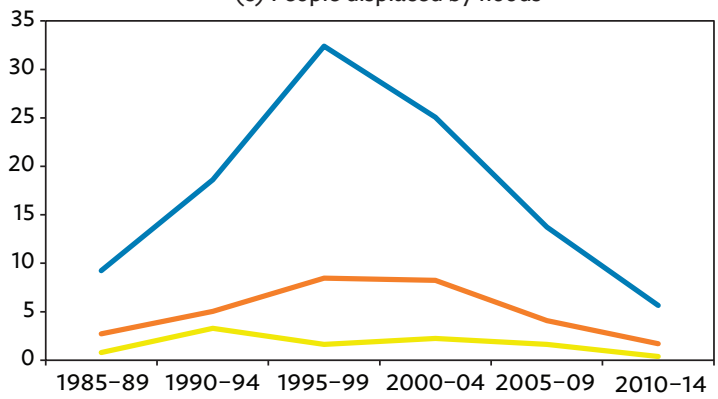

(e) Population in largest city

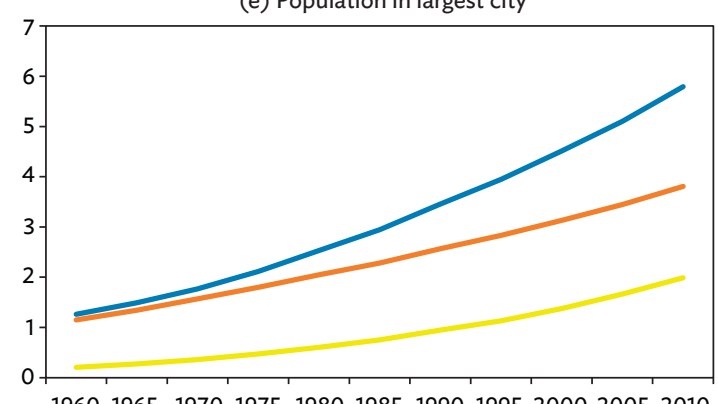

19601965197019751980198519901995200020052010 (b) Rainfall anomalies

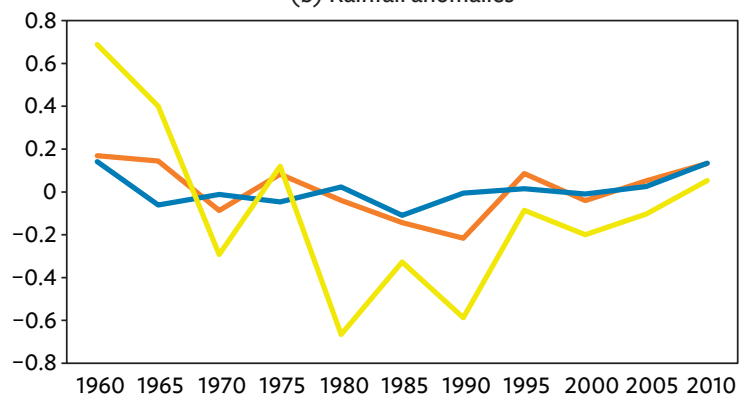

(d) Urban rate

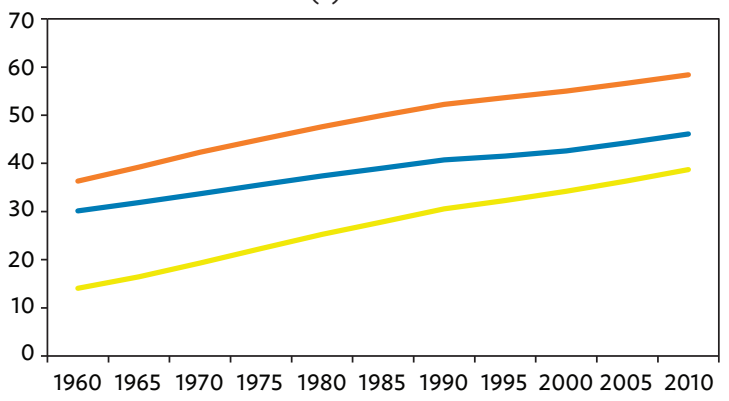

(f) Urban disorder events

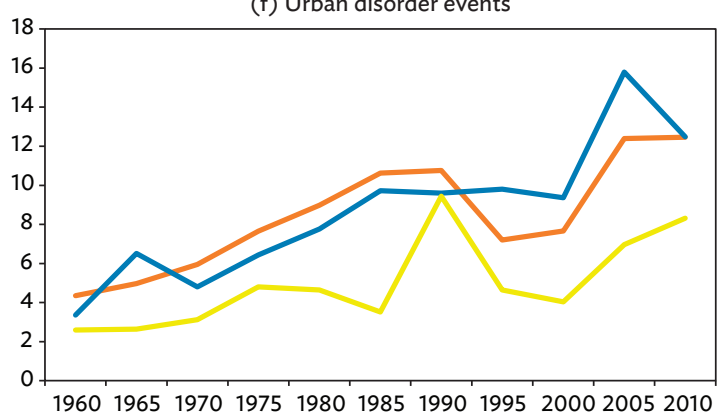

Sub-Saharan Africa

Notes: Trends show the average across countries. Data are aggregated to 5-year periods, except for urban populations, which are observed once every 5 years. Developing Asia is as defined by the Asian Development Bank. The sample of countries included in each category is limited by data availability. In Figure 1a, annual rainfall is measured in millimeters per year. In Figure 1b, rainfall anomalies are deviations from average rainfall, relative to country-specific year-to-year variations in rainfall. In Figure 1c, people displaced by floods are expressed per year as a percentage of the population in the largest city, relative to the size of the largest city. Note that data on floods are only observed for the period 1985-2015. In Figure 1e, population is measured in millions. In Figure 1f, urban disorders refer to the number of events, averaged across countries per period.

Source: Authors' calculations. 
Looking at Figure 1, we can highlight some relevant stylized facts. In terms of weather shocks, our data show a clear decreasing trend from 1960 to 1990 in SSA, both in terms of annual rainfall and rainfall anomalies (Figure 1a and $1 \mathrm{~b}$ ). Decreasing, and more erratic, rainfall in many SSA countries has been highlighted as a cause of rapid urbanization and lower economic performance in the last decades of the 20th century (for example, Barrios, Bertinelli, and Strobl 2006; 2010). In developing Asia, by contrast, rainfall levels are not only significantly higher than in SSA (and our world sample average), but also show lower anomalies. When looking at data on people displaced by floods, substantial differences between SSA and developing Asia are also evident; in developing Asia, the average across countries in the number of people displaced by floods is much higher than in SSA or any other region of the world (even relative to the population of the largest city, as shown in Figure 1c). The number of people displaced by floods in developing Asia shows a substantial increase between 1990 and 2000, when, on average, the number displaced by flooding per year per country was more than $30 \%$ of the population in the largest city in that country.

In terms of urban growth (Figure 1d), there is a clear upward trend in both developing Asia and SSA. However, the urban rate in SSA countries remains lower than in the rest of the world. On average, there is still at least a 10 percentage point difference between SSA and Asian countries. Something similar is evident when we look at the size of the largest cities; while in SSA, the average across countries in size of the largest city was still below 2 million inhabitants in 2010, in developing Asia, that figure was almost 6 million.

Finally, in terms of conflict in urban areas (Figure 1f), there is also a clear upward trend in the number of urban disorder events. In developing Asia, the number of events was above the world average since 1995, and it shows a significant rise between the year 2000 and 2005. Interestingly, for developing Asia, the trends of our key variables show i) a substantial increase in the number of displaced people by floods from 1990 to 2000, ii) an acceleration in the size of the largest cities right after (between 1995 and 2005), and iii) a significant increase in the number of urban disorder events after 2000.

To (descriptively) explore the potential connection between our key dimensions (weather shocks, urbanization and city growth, and conflict in urban areas), Figures $2 a-2 d$ show the association between some of our main variables. People displaced by floods shows a positive association with urban disorder events, especially in developing Asia. It also shows a positive association with the size of the largest city. This association is stronger when considering only floods that have not affected the largest city. ${ }^{7}$ Finally, the size of the largest city is also positively associated with the number of urban disorder events.

7 By contrast, rainfall anomalies show no association with urbanization (and size of the largest city) in the whole sample, but are negatively associated in SSA (in line with the literature). 


\section{Figure 2: Association between Main Variables}

(a) Floods and conflict

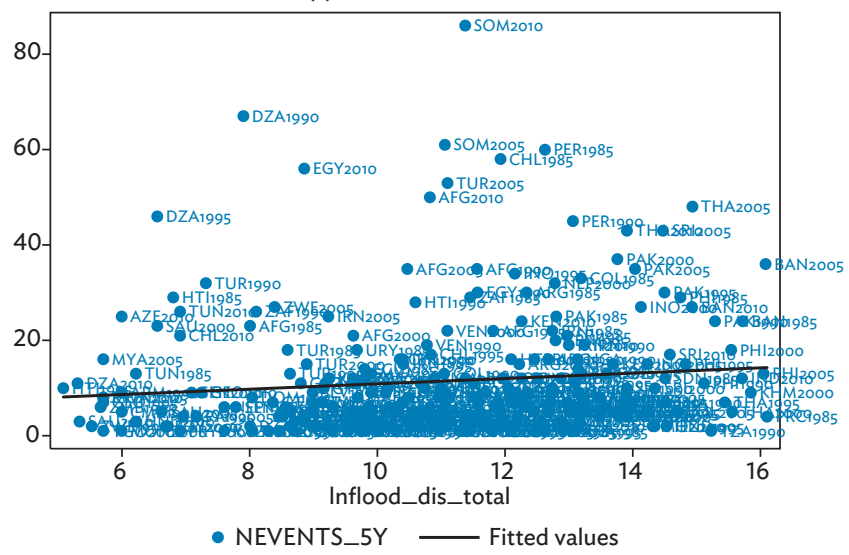

(c) Floods and population in the largest city

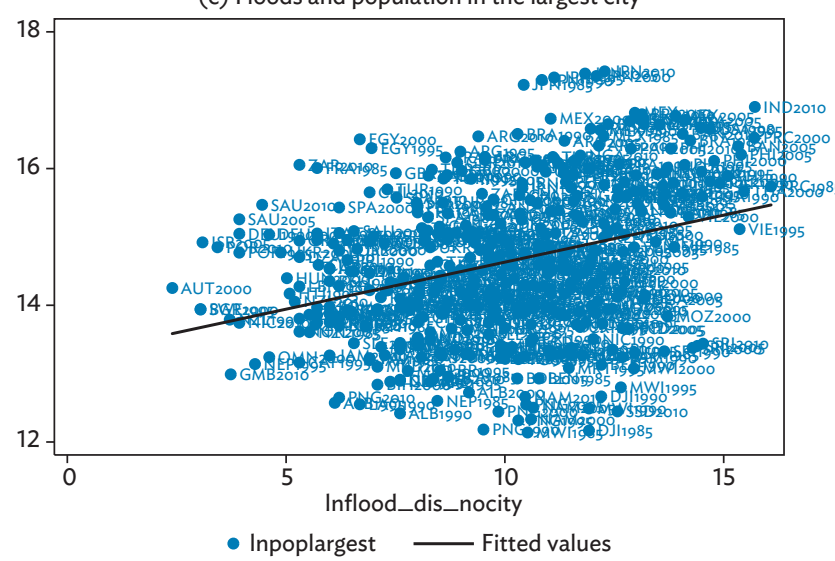

(b) Floods and conflict, developing Asia

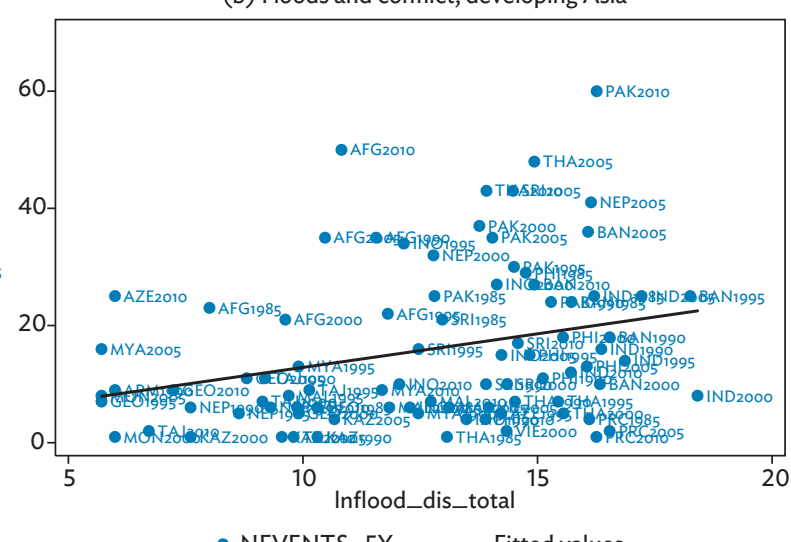

- NEVENTS_5Y — Fitted values

(d) Population in the largest city and urban disorder events

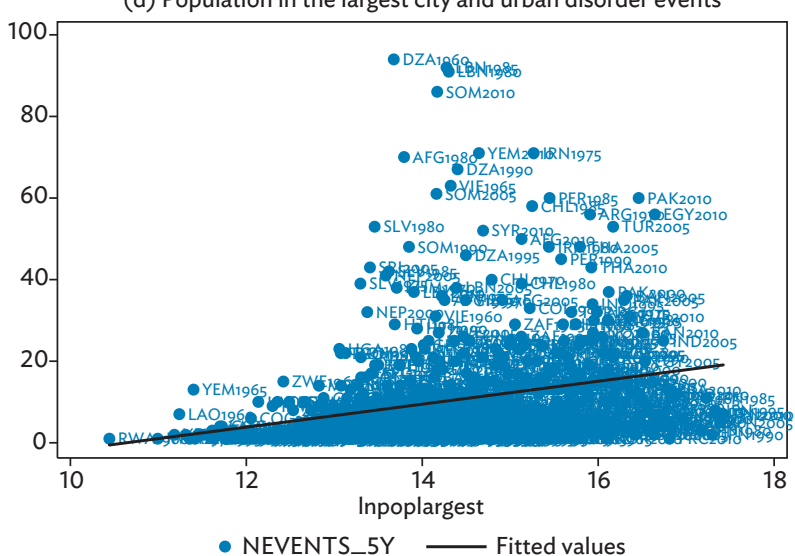

Notes: Figures show scatters using all available observations for each pair of variables. Figures $2 \mathrm{a}$ and $2 \mathrm{~b}$ show the number of urban social disorder events and population displaced by flooding, for the full sample (a) and for developing Asia only (b). Figure 2c excludes Japan as an outlier in the population of the largest agglomeration (Tokyo). Figure $2 \mathrm{~d}$ excludes Iraq as an outlier in urban disorder events. Source: Authors' calculations.

\section{EMPIRICAL ANALYSIS}

Our analysis involves a panel dataset covering the period 1960-2015 (1985-2015 for the floods data), for 138 (large) cities in 138 countries (one city per country). At the city level, we observe population and urban disorder events. Our main explanatory variables of interest-weather shocks and floodsare defined at the country level, given that we expect weather shocks outside of cities to "push" population into (large) cities. ${ }^{8}$ Similarly, (most of) our control variables - for example, GDP per capita and total population-are observed at the national level.

8 Population movement inside a country is much more likely (and easier) than across a border. For that reason, and for simplicity of the analysis, we do not consider the possibility of cross-border movements of population. 
Our sample of cities represents the largest city in each country (in terms of population in the urban agglomeration) and is based on the availability of the USD conflict data, which is generally only observed for one city per country. Where USD data for more than one city in a given country is available, we restrict our attention to the single largest city (usually, but not always, the capital city).

In estimation, our sample size is sometimes restricted due to the availability of our key variables. For example, while we have 138 cities in our sample, in specifications with urban disorder events as the outcome, the sample is restricted to those countries in the USD data, leaving us with a sample of 85 cities with data on urban social disorder events. Similarly, in terms of time coverage, our data spans from 1960 to 2015 (based on availability of the USD data). However, in regressions using flood data, we are restricted to the period 1985-2015, given the coverage of the flood events for which we have obtained maps (shapefiles) of affected areas, from the DFO archive (as detailed above).

\section{A. Estimation Strategy}

As our focus is on how weather shocks can "push" people into cities and therefore drive urban disorders there, we begin by testing the association between weather shocks-rainfall anomalies, mean temperature, and people displaced by floods - on the evolution of city size. We run regressions of the following form:

$$
\text { CitySize }_{i t}=\alpha_{1}+\beta_{1} \text { WeatherShocks }_{i t}+\beta_{2}{ }^{\prime} \boldsymbol{X}_{i t}+\gamma_{t}+\theta_{i}+\epsilon_{i t}
$$

where CitySize $_{i t}$ is the total population of the largest city (in logs) in country $i$ in period $t$ (where $t=$ $1960,1965,1970$...etc.). Alternatively, we also consider the log of the urbanization rate (the population living in urban areas as a percentage of the total population) in country $i$ in period $t .{ }^{9}$ City size and urbanization rates are observed every 5 years (i.e., in 1960, 1965, 1970... etc.). Our main explanatory variables of interest are WeatherShocksit. Depending on the specification, these are either rainfall anomalies (as defined above) and annual temperatures, or the log of the number of people displaced by floods (again, as discussed above). The $\boldsymbol{X}_{i t}$ are a set of time-varying country-level controls, including the log of GDP per capita and total country population..$^{\circ}$ We also include year fixed effects, $\gamma_{t}$, and city (country) fixed effects, $\theta_{i}$. The standard errors, $\varepsilon_{i t}$, are clustered at the city (country) level.

Our second step is to test the "reduced-form" of our main hypothesis: that weather shocks, in particular, the number of people displaced by flooding outside of major cities, are associated with urban disorder within those cities. For this, we estimate regressions of the following form:

$$
\text { Disorder }_{i j t}=\alpha_{1}+\beta_{1} \text { Floods }_{i t}+\beta_{2} \text { CitySize }_{i t}+\beta_{3}{ }^{\prime} \boldsymbol{X}_{i t}+\gamma_{t}+\theta_{i}+\epsilon_{i t}
$$

where Disorder $i j t$ represents a measure of the number of events, of type $j$ where $j=\{$ all, fatal, nonfatal $\}$, in city $i$ in period $t$, where $t$ aggregates the number of events every 5 years for the period 1960-2015 (as observed in the USD data). We distinguish in the data between events that involved fatalities and those that did not. Floods $s_{i t}$ is defined, as discussed above, as the log of the number of people displaced by flood events that occurred in country $i$ in period $t$ (1985-2015), which did not overlap with the largest city (where the disorder events are observed).

9 We take the log of the urbanization rate to replicate the empirical set-up in Barrios, Bertinelli, and Strobl (2006).

10 Where these controls are included alongside WeatherShocksit, the controls are lagged in order to avoid weather shocks (or floods) having a contemporaneous effect on these controls. 
Equation (2) is estimated using count models when Disorder ijt $_{\text {it }}$ measured as a count of events for a given city-period observation. "This approach tests the intensive margin of the effect of floods (and city population) on the frequency of disorder events. Alternatively, equation (2) can be estimated using a probability model when Disorder $r_{i j t}$ is measured as a binary indicator for city-period observations with zero or nonzero counts of disorder events of a particular type. ${ }^{12}$ In this case, equation (2) would test the extensive margin of the effect of floods (and city population) on the likelihood of (a particular type of) urban disorder. The remaining variables on the right-hand side of equation (2) are defined as in equation (1), with the difference that here we include CitySize $_{i t}$ alongside our main explanatory variable. We also include additional control variables relevant for explaining social disorder in urban areas, such as an indicator for country-periods with ongoing armed conflict, and an indicator of democracy. ${ }^{13}$ We first estimate versions of equation (2) without including city size on the right-hand side, to test for any significant association between people displaced by floods and urban disorder. We then include city size, to test our idea that the association between people displaced by floods on urban disorder is operating (primarily) through the displacement of population into (large) cities.

Our primary hypothesis is therefore as follows: floods occurring outside of cities displace people, leading to an increase in city population, resulting in increased urban social disorder. This general hypothesis leads to two testable hypotheses, based on estimating equation (2):

$\mathrm{H} 1: \boldsymbol{\beta}_{1}>0$, where CitySize $_{i t}$ is not included in equation (2)

$\mathrm{H} 2: \beta_{2}>0$ and $\beta_{1}=0$, where CitySize $e_{i t}$ is included in equation (2)

$\mathrm{H} 1$ predicts that the number of people displaced by floods that occur outside a city is positively associated with urban social disorder events in the city. $\mathrm{H} 2$ predicts that this effect is mediated via the effect of floods on city population, and the consequent effect of city population on urban social disorder. $\mathrm{H} 2$ predicts that the only effect of floods on urban social disorder is via the effect of floods on city population (i.e., city size). A weaker version of $\mathrm{H} 2$ would be that the magnitude of the coefficient on floods $\left(\boldsymbol{\beta}_{1}\right)$ would decrease (and/or become less statistically significant), when CitySize $e_{i t}$ is added to equation (2), indicating that some (but not all) of the effect of floods on urban social disorder is happening via the effects on city population.

${ }^{11}$ Given overdispersion in the urban disorder events data, we report the results of estimation using a negative binomial model as our baseline, although we have also experimented with a Poisson model, with (qualitatively) similar findings.

12 Where we estimate equation (2) using a probit model, the specification includes random effects, as opposed to fixed effects. If we include country fixed effects (or country dummies), the relative lack of variation in the binary outcome at the country level results in many countries being dropped (due to collinearity) with a substantial decrease in the number of observations and precision of the findings. This is particularly an issue for the shorter panel where we use floods data (1985-2015).

13 These additional controls are based on the UCDP/PRIO Armed Conflict Data Set (Uppsala Conflict Data Program and Peace Research Institute Oslo 1946-2008), and the Polity IV Project: Political Regime Characteristics and Transitions data on democracy (Marshall and Gurr, 1800-2013), respectively. 
Finally, we test the effects of city size on urban social disorder directly, by running regressions of the following form:

$$
\text { Disorder }_{i j t}=\alpha_{1}+\beta_{1} \text { CitySize }_{i t}+\beta_{2} \boldsymbol{X}_{i t}+\gamma_{t}+\theta_{i}+\epsilon_{i t}
$$

where variables are defined as in equations (1) and (2) above. Equation (3) is also estimated for both the extensive and intensive margins, as discussed above for equation (2).

\section{B. Results}

We start with regressions of city size and urbanization rates on weather shocks (as in equation [1]). The first set of results, presented in Table 2, shows the effect of rainfall anomalies on city size. In general, we find a strong negative association between rainfall anomalies and city size-periods with low rainfall are associated with higher city size. This is particularly the case in SSA. However, in Asia, we find the opposite pattern-higher rainfall is associated with city growth.

Table 2: Effect of Weather Shocks on City Population (Log)

\begin{tabular}{lrrrrrr}
\hline Variables & \multicolumn{1}{c}{$(1)$} & \multicolumn{1}{c}{$(2)$} & \multicolumn{1}{c}{$(3)$} & \multicolumn{1}{c}{$(4)$} & \multicolumn{1}{c}{$(5)$} & \multicolumn{1}{c}{$(6)$} \\
\hline Rainfall anomalies $(t-1)$ & $-0.049^{* * *}$ & 0.002 & $-0.062^{* * *}$ & $-0.062^{* * *}$ & -0.008 & $-0.086^{* * *}$ \\
& $(0.016)$ & $(0.015)$ & $(0.016)$ & $(0.021)$ & $(0.020)$ & $(0.022)$ \\
Rainfall anomalies $(t-1) \times$ SSA & & $-0.162^{* * *}$ & & & $-0.143^{* * *}$ & \\
& & $(0.037)$ & & & $(0.042)$ & \\
Rainfall anomalies $(t-1) \times$ & & & & & & $0.119^{* * *}$ \\
devAsia & & & $\left(0.042^{*}\right.$ & & & $(0.043)$ \\
Temperature $(t-1)$ & -0.045 & $-0.122^{* * *}$ & $-0.063^{*}$ & -0.015 & $-0.129^{* *}$ & -0.046 \\
& $(0.032)$ & $(0.037)$ & $(0.036)$ & $(0.041)$ & $(0.052)$ & $(0.044)$ \\
Temperature $(t-1) \times$ SSA & & $0.355^{* * *}$ & & & $0.325^{* * *}$ & \\
& & $(0.109)$ & & & $(0.106)$ & \\
Temperature $(t-1) \times$ devAsia & & & $0.215^{* *}$ & & & $0.203^{*}$ \\
Observations & & & $(0.108)$ & & & $(0.111)$ \\
R-squared & 1,294 & 1,294 & 1,294 & 884 & 884 & 884 \\
Number of countries & 0.839 & 0.856 & 0.842 & 0.846 & 0.860 & 0.849 \\
Controls & 134 & 134 & 134 & 101 & 101 & 101 \\
\hline
\end{tabular}

$\operatorname{dev}$ Asia = developing Asia, SSA = sub-Saharan Africa.

Notes: Robust standard errors, clustered by country, in parentheses. Country and time period fixed effects included in all models. ${ }^{* * *} p<0.01,{ }^{* *} p<0.05,{ }^{*} p<0.1$. Rainfall anomalies are measured as annual deviations from rainfall relative to the variability of year-to-year rainfall; annual temperature is measured in Celsius degrees. The outcome variable in each model is log (city population) for the largest city in each country. Additional controls included: log (gross domestic product per capita) and log (total population).

Source: Authors' calculations. 
Table 3: Effect of Weather Shocks on Urbanization Rate (Log)

\begin{tabular}{|c|c|c|c|c|c|c|}
\hline Variables & (1) & (2) & (3) & (4) & (5) & (6) \\
\hline Rainfall anomalies $(t-1)$ & $\begin{array}{r}-0.034^{* * *} \\
(0.010)\end{array}$ & $\begin{array}{r}-0.001 \\
(0.008)\end{array}$ & $\begin{array}{r}-0.044^{* * *} \\
(0.011)\end{array}$ & $\begin{array}{r}-0.027^{* *} \\
(0.011)\end{array}$ & $\begin{array}{r}0.004 \\
(0.011)\end{array}$ & $\begin{array}{r}-0.041^{* * *} \\
(0.012)\end{array}$ \\
\hline Rainfall anomalies $(t-1) \times$ SSA & & $\begin{array}{r}-0.098^{* * *} \\
(0.024)\end{array}$ & & & $\begin{array}{r}-0.084^{* * *} \\
(0.025)\end{array}$ & \\
\hline $\begin{array}{l}\text { Rainfall anomalies } \\
(t-1) \times \operatorname{dev} \text { Asia }\end{array}$ & & & $\begin{array}{r}0.053^{*} \\
(0.028)\end{array}$ & & & $\begin{array}{l}0.067^{* *} \\
(0.026)\end{array}$ \\
\hline Temperature $(t-1)$ & $\begin{array}{l}-0.008 \\
(0.024)\end{array}$ & $\begin{array}{r}-0.067^{* * *} \\
(0.024)\end{array}$ & $\begin{array}{r}-0.021 \\
(0.025)\end{array}$ & $\begin{array}{r}0.045 \\
(0.034)\end{array}$ & $\begin{array}{r}-0.041 \\
(0.034)\end{array}$ & $\begin{array}{r}0.028 \\
(0.036)\end{array}$ \\
\hline Temperature $(t-1) \times \mathrm{SSA}$ & & $\begin{array}{c}0.242^{* * *} \\
(0.078)\end{array}$ & & & $\begin{array}{c}0.243^{* * *} \\
(0.079)\end{array}$ & \\
\hline Temperature $(t-1) \times \operatorname{devAsia}$ & & & $\begin{array}{r}0.131 \\
(0.104)\end{array}$ & & & $\begin{array}{r}0.110 \\
(0.102)\end{array}$ \\
\hline Observations & 1,160 & 1,160 & 1,160 & 884 & 884 & 884 \\
\hline R-squared & 0.648 & 0.683 & 0.653 & 0.692 & 0.723 & 0.696 \\
\hline Number of iso num & 134 & 134 & 134 & 101 & 101 & 101 \\
\hline Controls & $\checkmark$ & $\checkmark$ & $\checkmark$ & $\checkmark$ & $\checkmark$ & $\checkmark$ \\
\hline
\end{tabular}

$\operatorname{dev}$ Asia = developing Asia, SSA = sub-Saharan Africa.

Notes: Robust standard errors, clustered by country, in parentheses. Country and time period fixed effects included in all models. ${ }^{* * *} p<0.01$, ${ }^{* *} p<0.05,{ }^{*} p<0.1$. Rainfall anomalies are measured as annual deviations from rainfall relative to the variability of year-to-year rainfall; annual temperature is measured in Celsius degrees. The outcome variable in each model is log (urbanization rate). Additional controls included: log (gross domestic product per capita) and log (total population).

Source: Authors' calculations.

In column (1) of Table 2, which includes the full sample, we find a significant negative association between rainfall anomalies and city size. Column (2) repeats this specification allowing for differentiated coefficients for SSA countries (cities). Column (3) allows for differentiated coefficients for developing Asia. While for SSA, the coefficient for rainfall is negative, for developing Asia, it is positive, reversing the overall effect of rainfall anomalies on city population. Columns (4), (5), and (6) repeat column (1), (2), and (3) restricting the sample to developing countries only, showing similar results, with more precision on the interaction term between rainfall anomalies and developing Asia. ${ }^{14}$

We also run regressions for equation (1) but considering urbanization rates, reported in Table 3, rather than the size of the largest city as reported in Table 2. Like the results in Table 2, we find that lower-than-expected rainfall leads to higher urbanization in SSA, but the opposite pattern for developing Asia. ${ }^{15}$ While the (negative) association between rainfall anomalies and urbanization

14 In further robustness checks not reported here, we repeated the specifications in Table 2 excluding outliers in terms of city population (Tokyo). The results remain essentially unaffected. Results available on request.

15 As with Table 2, we also run further robustness checks not reported here, repeating the specifications in Table 3, excluding outliers in terms of city population (Tokyo), and including both interaction terms (with SSA and developing Asia) in the same regression. In all cases, the results remain essentially unaffected. Results available on request. 
has been observed previously for Africa (for example, Barrios, Bertinelli, and Strobl 2006), the observation of a positive association between rainfall anomalies and city growth for Asia is relatively novel. The reversal of the sign on rainfall anomalies for Asia may appear confusing. One potential explanation is that higher rainfall is associated with more economic growth and therefore faster city growth in developing Asia. However, we do not find such an association-in fact, in results not reported here, we find that if anything, rainfall anomalies are negatively associated with economic growth in developing Asia. ${ }^{16}$ Instead, we believe our finding may come from what rainfall anomalies mean in each region, and hint to differential effects of climate change in different world regions. In (most of) Africa, rainfall is already scarce, and shows a clear decreasing trend over the last decades. A negative anomaly in our data means lower-than-expected rainfall-a negative productivity shock to agriculture-potentially pushing people from rural to urban areas. By contrast, in developing Asia, a positive rainfall anomaly in our data may be associated with too much rain (and therefore the risk of floods). In other specifications, not reported here, we also experimented with interactions between rainfall anomalies and an indicator for countries with high average annual rainfall. The findings from this exercise also suggest that "too much" rainfall is associated with faster growth of large cities in countries with already high levels of rainfall."

Where flooding occurs in rural areas, the displaced population may be pushed toward cities. We test this hypothesis more explicitly in the next set of results.

In Table 4, we test the effect of flooding on city population. ${ }^{18}$ We limit our attention to people displaced by flood events that did not occur in a country's largest city (see discussion of this in the data section). Here, we find that the numbers of people displaced by floods occurring outside of our large cities are associated with (changes in) the population in the city-indicating that people displaced by floods are "pushed" toward the largest urban areas. We find no evidence of significant regional variation in this case - the interactions with the SSA or developing Asia dummies are not significant. The effects of flooding on population in cities is similar for the full sample (in columns 1-3) and when we restrict to "developing" countries only (columns 4-6). As both people displaced by floods and city population are in logs, we can interpret our coefficient as elasticities. According to our coefficients, a $1 \%$ increase in people displaced by flood leads to around a $0.004 \%$ increase in the population of the largest city. This may look like a small number, but in absolute terms, the number is not negligible. For example, according to our data, in Thailand, between 2000 and 2005, the period of the big tsunami of 2004, around 5 million people were displaced by floods outside Bangkok. According to our estimates, this translates into around 128,000 more residents in Bangkok attributable only to the effect of flooding outside Bangkok.

16 We perform growth regressions in a similar spirit to the analysis reported in Barrios, Bertinelli, and Strobl (2010). For Africa, we find something similar to Barrios, Bertinelli, and Strobl (2010): more rainfall is associated with higher economic growth. For developing Asia, we found the opposite: more rainfall, if anything, is associated with less growth. Results available on request.

17 Results available on request.

18 Note the sample size drops considerably here-mainly due to the more limited time coverage in the flooding data, which is only available since 1985 . 
Table 4: Effect of Floods on City Population (Log)

\begin{tabular}{lrrrrrr}
\hline Variables & \multicolumn{1}{c}{$(1)$} & \multicolumn{1}{c}{$(2)$} & \multicolumn{1}{c}{$(3)$} & \multicolumn{1}{c}{$(4)$} & \multicolumn{1}{c}{$(5)$} & \multicolumn{1}{c}{$(6)$} \\
\hline Floods $(t-1)$ & $0.004^{* * *}$ & $0.003^{* *}$ & $0.004^{* *}$ & $0.005^{* * *}$ & 0.003 & $0.004^{* *}$ \\
& $(0.002)$ & $(0.001)$ & $(0.002)$ & $(0.002)$ & $(0.002)$ & $(0.002)$ \\
Floods $(t-1) \times$ SSA & & 0.004 & & & 0.005 & \\
& & $(0.004)$ & & & $(0.004)$ & \\
Floods $(t-1) \times$ devAsia & & & 0.006 & & & 0.006 \\
& & & $(0.006)$ & & & $(0.006)$ \\
Observations & 778 & 778 & 778 & 486 & 486 & 486 \\
R-squared & 0.812 & 0.812 & 0.812 & 0.799 & 0.801 & 0.800 \\
Number of countries & 138 & 138 & 138 & 104 & 104 & 104 \\
Controls & $\checkmark$ & $\checkmark$ & $\checkmark$ & $\checkmark$ & $\checkmark$ & $\checkmark$ \\
\hline
\end{tabular}

$\operatorname{dev}$ Asia = developing Asia, SSA = sub-Saharan Africa.

Notes: Robust standard errors, clustered by country, in parentheses. City and time period fixed effects included in all models. ${ }^{* *} p<0.01$, ${ }^{* *} p<0.05,{ }^{*} p<0.1$. Floods is in logs and is measured as the people displaced by flood events which did not overlap with a country's largest city. The outcome variable in each model is log (city population) for the largest city in each country. Columns 1-3 include the full sample, columns 4-6 include only developing countries. Additional controls included: log (gross domestic product per capita) and log (total population), both lagged.

Source: Authors' calculations.

Next, we turn to estimating equation (2) - the core of our empirical analysis - for the reduced form effects of floods on urban disorder. The results in Tables 5 and 6 suggest that the numbers displaced by floods occurring outside major cities are strongly associated with (the evolution of) the number of disorder events occurring in those cities (the "intensive margin"-Table 5), and with the probability of observing disorder events in a given city (the "extensive margin"-Table 6), as anticipated in $\mathrm{H} 1$. In Table 5 , the results show that floods are positively related to the count of all disorder events at the city level (column 1), and the count of fatal events (column 3), while the estimated coefficient on floods is positive but not statistically significant for nonfatal events (in column 5). Similarly, the results in Table 6 show that floods are positively associated with the probability of observing urban disorder events (total—column 1; fatal-column 3; and nonfatal—column 5).

In Tables 5 and 6 we also test $\mathrm{H} 2$-that the effects of floods on urban disorder operate (mainly) via city population-by adding it as an additional control (in columns 2, 4, and 6 of Tables 5 and 6). In each case, we see the magnitude of the coefficient on floods declines, and becomes less statistically significant, when we add city population, indicating that (most of) the effect of floods on urban disorder is indeed operating via the effects of flooding on city population. The coefficient on city population is positive and significant in all cases. These findings would seem to support the expectation expressed in $\mathrm{H} 2$. The findings reported in Tables 5 and 6 are robust to the inclusion of indicators for country-periods with ongoing armed conflicts, and for democracy. ${ }^{19}$

19 The results are also robust to the exclusion of outliers in terms of city population (Japan), numbers displaced by flooding (India and Indonesia) and frequency of urban disorder events (Iraq). Results available on request. 
Table 5: Effect of Floods on Urban Conflict Events, Intensive Margin

\begin{tabular}{lcccccc}
\hline Variables & $(1)$ & $(2)$ & $(3)$ & $(4)$ & $(5)$ & $\begin{array}{c}(6) \\
\text { Fatal }\end{array}$ \\
\hline Floods $(t-1)$ & All & \multicolumn{1}{c}{ All } & Fatal & Fanfatal & Nonfatal \\
& $0.033^{* * *}$ & $0.025^{*}$ & $0.030^{* *}$ & 0.021 & 0.017 & 0.008 \\
City population & $(0.012)$ & $(0.013)$ & $(0.015)$ & $(0.016)$ & $(0.013)$ & $(0.014)$ \\
& & $0.232^{* *}$ & & $0.235^{*}$ & & $0.280^{* *}$ \\
Observations & & $(0.117)$ & & $(0.143)$ & & $(0.138)$ \\
Number of countries & 384 & 384 & 359 & 359 & 384 & 384 \\
Controls & 80 & 80 & 75 & 75 & 80 & 80 \\
\hline
\end{tabular}

Notes: All models estimated using a negative binomial model with country and time period fixed effects. Standard errors in parentheses. *** $p<0.01,{ }^{* *} p<0.05,{ }^{*} p<0.1$. Floods is in logs and is measured as the people displaced by flood events which did not overlap with a country's largest city; city population is the log of the population in the largest city. The outcome variable in columns (1) and (2) is the count of all urban social disorder events observed for each city; in columns (3) and (4) the count of disorder events that involved fatalities; and in columns (5) and (6) the count of disorder events that did not involve fatalities. Additional control included: log (gross domestic product per capita).

Source: Authors' calculations.

Table 6: Effect of Floods on Urban Conflict Events, Extensive Margin

\begin{tabular}{|c|c|c|c|c|c|c|}
\hline Variables & $\begin{array}{l}\text { (1) } \\
\text { All }\end{array}$ & $\begin{array}{l}\text { (2) } \\
\text { All }\end{array}$ & $\begin{array}{l}\text { (3) } \\
\text { Fatal }\end{array}$ & $\begin{array}{l}\text { (4) } \\
\text { Fatal }\end{array}$ & $\begin{array}{c}(5) \\
\text { Nonfatal }\end{array}$ & $\begin{array}{c}(6) \\
\text { Nonfatal }\end{array}$ \\
\hline Floods $(t-1)$ & $\begin{array}{c}0.063^{* * *} \\
(0.024)\end{array}$ & $\begin{array}{r}0.038 \\
(0.025)\end{array}$ & $\begin{array}{r}0.050^{* * *} \\
(0.019)\end{array}$ & $\begin{array}{r}0.035^{*} \\
(0.020)\end{array}$ & $\begin{array}{l}0.058^{* *} \\
(0.023)\end{array}$ & $\begin{array}{r}0.031 \\
(0.024)\end{array}$ \\
\hline City population & & $\begin{array}{l}0.416^{* *} \\
(0.191)\end{array}$ & & $\begin{array}{c}0.255^{*} \\
(0.137)\end{array}$ & & $\begin{array}{c}0.521^{* * *} \\
(0.182)\end{array}$ \\
\hline Observations & 389 & 389 & 389 & 389 & 389 & 389 \\
\hline Number of countries & 82 & 82 & 82 & 82 & 82 & 82 \\
\hline Controls & $\checkmark$ & $\checkmark$ & $\checkmark$ & $\checkmark$ & $\checkmark$ & $\checkmark$ \\
\hline
\end{tabular}

Notes: Probit random effects model, with time period fixed effects included in all models. Robust standard errors in parentheses. ${ }_{* * *} p<0.01,{ }^{* *} p<0.05,{ }^{*} p<0.1$. Floods is in logs and is measured as the people displaced by flood events which did not overlap with a country's largest city; city population is the log of the population in the largest city. The outcome variable in columns (1) and (2) is a binary indicator for whether or not urban social disorder events of any type are observed for each city; in columns (3) and (4) a similar indicator but for events that involved fatalities only; and in columns (5) and (6) a similar indicator for events that did not involve fatalities. Additional control included: log (gross domestic product per capita).

Source: Authors' calculations. 
Finally, we test directly for association between city population and the frequency (and probability) of urban disorder events. In Table 7, we report the estimated effect of (log) city population on the count of disorder events at the city level (in columns 1-3) and on the probability of observing disorder events (in columns 4-6). We find that increases in city population are significantly associated with higher counts of disorder events (column 1), of fatal events (column 2), as well as nonfatal events (column 3). Turning to the extensive margin, results in columns $4-6$ suggest that city population is associated with a higher probability of urban disorder events (again, total, fatal, and nonfatal). ${ }^{20}$

Table 7: Effect of City Population on Urban Conflict Events, Intensive, and Extensive Margins

\begin{tabular}{lcccccc}
\hline & $\begin{array}{c}(1) \\
\text { All Count } \\
\text { Model }\end{array}$ & $\begin{array}{c}\text { Fatal Count } \\
\text { Model }\end{array}$ & $\begin{array}{c}(3) \\
\text { Nonfatal } \\
\text { Count Model }\end{array}$ & $\begin{array}{c}(4) \\
\text { All } \\
\text { Prob Model }\end{array}$ & $\begin{array}{c}(5) \\
\text { Fatal Prob } \\
\text { Model }\end{array}$ & $\begin{array}{c}\text { Nonfatal Prob } \\
\text { Model }\end{array}$ \\
\hline City population & $0.316^{* * *}$ & $0.255^{* * *}$ & $0.312^{* * *}$ & $0.417^{* * *}$ & $0.288^{* * *}$ & $0.415^{* * *}$ \\
& $(0.059)$ & $(0.073)$ & $(0.066)$ & $(0.106)$ & $(0.096)$ & $(0.090)$ \\
Observations & 820 & 798 & 820 & 825 & 825 & 825 \\
Number of & 84 & 82 & 84 & 85 & 85 & 85 \\
countries & & $\checkmark$ & $\checkmark$ & $\checkmark$ & $\checkmark$ & $\checkmark$ \\
Controls & $\checkmark$ & $\checkmark$ & $\checkmark$ & & $\checkmark$ & $\checkmark$ \\
\hline
\end{tabular}

Notes: Columns (1)-(3) were estimated using a negative binomial model with unit and time period fixed effects. Columns (4)-(6) were estimated using a probit model with random effects and time period fixed effects. ${ }^{* *} p<0.01,{ }^{* *} p<0.05,{ }^{*} p<0.1$. City population is the log of the population in the largest city. The outcome variable in columns (1)-(3) is a count of all urban social disorder events (1), fatal events (2) and nonfatal events (3). In columns (4)-(6), the outcome is a binary indicatory for city-periods with at least one disorder event of any type (4), involving a fatality (5), and not involving any fatalities (6). Additional control included: log (gross domestic product per capita).

Source: Authors' calculations.

\section{CONCLUSIONS, DISCUSSION, AND NEXT STEPS}

In the analysis presented in this paper, we begin by replicating an existing finding from the literaturethat lower-than-expected rainfall is associated with higher urbanization and city growth in countries in sub-Saharan Africa. However, we also establish a new finding related to rainfall anomalies: in developing Asia, higher- (rather than lower-) than-expected rainfall appears to be associated with faster growth of large cities and urbanization. We interpret this finding with reference to an overabundance of rainfall in developing Asia. For arid countries-including many in sub-Saharan Africa-low rainfall likely represents a negative productivity shock to agriculture, potentially pushing people from rural to urban areas. For wetter regions, including many developing Asian countries, the opposite may be the case-too much rainfall results in a negative productivity shock for agriculture (possibly associated with flooding), driving people from rural to urban areas.

20 The coefficients on city population are similar to those in Tables 5 and 6 , but are estimated more precisely here, given the larger number of observations (we can take advantage of the full sample period, 1960-2015, in Table 7, since we are not including floods data in these regressions). 
We test this hypothesis explicitly by drawing on novel data related to flooding. In particular, we distinguish between floods that impact directly on major cities, and those that occur outside of our sample of large cities. We find that the latter are strongly associated with the evolution of population in the major (developing) world cities that we study. We next turn to the central hypothesis of our paper, that the displacement of population by flooding leads to increased risk of urban disorder due to increasing congestion in urban areas as the population is "pushed" into cities as a result of floods elsewhere. We find evidence to support the direct effect of floods on urban disorder (both the count of events, the "intensive" margin, and the probability of observing a disorder event, the "extensive" margin), and evidence to support the hypothesized mechanism.

Our findings have important policy implications, especially for evaluating future climate change, as well as for policies regarding climate and disaster resilience, considering the connection between weather shocks and disasters, the spatial reallocation of population, and the tensions and conflict that can come with it.

Our findings also highlight the need for further research. As suggested by our differential findings for Africa and Asia, heterogeneities across countries with regards to baseline climate (arid versus humid countries), type of weather shocks expected, and potentially other country and/or city characteristics-for example, the share of agriculture in GDP_should be studied in more detail to understand the potential impact of climate change specific to each country. Exploring alternative datasets could also allow for more localized (spatially refined) analysis. Finally, a more explicit causal analysis of the different mechanisms linking weather shocks, urbanization and city growth, and disorder in urban areas could be explored, for instance by looking at data on local labor market outcomes, development of local infrastructure, income distribution, and other urban dynamics. 


\section{REFERENCES}

Alexandratos, Nikos. 2008. "Food Price Surges: Possible Causes, Past Experience, and Longer Term Relevance.” Population and Development Review 34 (4): 663-97.

Bairoch, Paul. 1988. Cities and Economic Development: From the Dawn of History to the Present. Chicago: University of Chicago Press.

Barrios, Salvador, Luisito Bertinelli, and Eric Strobl. 2006. "Climate Change and Rural-Urban Migration: The Case of Sub-Saharan Africa." Journal of Urban Economics 60 (3): 357-71.

- - 2010. "Trends in Rainfall and Economic Growth in Africa: A Neglected Cause of the African Growth Tragedy." Review of Economics and Statistics 92 (2): 350-66.

Bates, Robert. 1981. Markets and State in Tropical Africa. Berkeley: University of California Press.

Beall, Jo, Basudeb Guha-Khasnobis, and Ravi Kanbur. 2010. "Beyond the Tipping Point: A Multidisciplinary Perspective on Urbanization and Development." In Urbanization and Development: Multidisciplinary Perspectives, edited by Jo Beall, Basudeb Guha-Khasnobis, and Ravi Kanbur, 3-16. Oxford: Oxford University Press.

Benson, Charlotte, and Edward Clay. 1998. "The Impact of Drought on Sub-Saharan African Economies: A Preliminary Examination.” World Bank Technical Paper No. 401.

Bhavnani, Rikhil, and Bethany Lacina. 2015. "The Effects of Weather-Induced Migration on Sons of the Soil Riots in India.” World Politics 67 (4): 760-94.

Bohlken, Anjali T., and Ernest J. Sergenti. 2010. "Economic Growth and Ethnic Violence: An Empirical Investigation of Hindu-Muslim Riots in India.” Journal of Peace Research 47 (5): 589-600.

Brakenridge, Robert. 1985-present. "Global Active Archive of Large Flood Events." Dartmouth Flood Observatory, University of Colorado. http://floodobservatory.colorado.edu/ (accessed in 2018).

Bruckner, Markus. 2012. "Economic Growth, Size of the Agricultural Sector, and Urbanization in Africa." Journal of Urban Economics 71 (1): 26-36.

Brülhart, Marius, and Federica Sbergami. 2009. "Agglomeration and Growth: Cross-Country Evidence.” Journal of Urban Economics 65 (1): 48-63.

Buhaug, Halvard, and Henrik Urdal. 2013. "An Urbanization Bomb? Population Growth and Social Disorder in Cities." Global Environmental Change 23 (1): 1-10.

Castells-Quintana, David. 2017. "Malthus Living in a Slum: Urban Concentration, Infrastructure and Economic Growth." Journal of Urban Economics 98: 158-73. 
Castells-Quintana, David, Maria del Pilar Lopez-Uribe, and Thomas K.J. McDermott. 2018. "Adaptation to Climate Change: A Review through a Development Economics Lens." World Development 104: 183-96.

Ciccone, Antonio. 2011. "Economic Shocks and Civil Conflict: A Comment." American Economic Journal: Applied Economics 3 (4): 215-27.

- - - 2013. "Estimating the Effect of Transitory Economic Shocks on Civil Conflict." Review of Economics Institutions 4 (2): 1-14.

Collier, Paul, Gordon Conway, and Tony Venables. 2008. "Climate Change and Africa." Oxford Review of Economic Policy 24 (2): 337-53.

Couttenier, Matthieu, and Raphael Soubeyran. 2014. "Drought and Civil War in Sub-Saharan Africa." Economic Journal 124 (575): 201-44.

Eriksen, Siri, and Jeremy Lind. 2009. "Adaptation as a Political Process: Adjusting to Drought and Conflict in Kenya's Drylands.” Environmental Management 43 (5): 817-35.

Gizewski, Peter, and Thomas Homer-Dixon. 1995. "Urban Growth and Violence: Will the Future Resemble the Past?" Occasional paper, Project on Environment, Population and Security. Washington, DC: American Association for the Advancement of Science and the University of Toronto.

Gray, Clark L., and Valerie Mueller. 2012. "Natural Disasters and Population Mobility in Bangladesh.” Proceedings of the National Academy of Science 109 (16): 6000-6005.

Hallegatte, Stephane, Colin Green, Robert J. Nicholls, and Jan Corfee-Morlot. 2013. "Future Flood Losses in Major Coastal Cities." Nature Climate Change 3: 802-806.

Harris, Ian, Philip Jones, Timothy John Osborn, and David Lister. 2014. "Updated High-Resolution Grids of Monthly Climatic Observations - The CRU TS3.10 Dataset." International Journal of Climatology 34 (3): 623-42. doi:10.1002/joc.3711.

Henderson, J. Vernon. 2003. "The Urbanization Process and Economic Growth: The So-What Question.” Journal of Economic Growth 8 (1): 47-71.

Henderson, J. Vernon, Adam Storeygard, and Uwe Deichmann. 2014. "50 Years of Urbanization in Africa: Examining the Role of Climate Change." World Bank Policy Research Working Paper No. 6925.

- - . 2017. "Has Climate Change Driven Urbanization in Africa?" Journal of Development Economics 124: 60-82.

Hendrix, Cullen S. 2010. "Measuring State Capacity: Theoretical and Empirical Implications for the Study of Social Conflict." Journal of Peace Research 47(3): 273-85. 
Hendrix, Cullen S., and Idean Salehyan. 2012. "Climate Change, Rainfall, and Social Conflict in Africa." Journal of Peace Research 49 (1): 35-49.

Jensen, Peter Sandholt, and Kristian Skrede Gleditsch. 2009. "Rain Growth and Civil War: The Importance of Location." Defence \& Peace Economics 20 (5): 359-72.

Jongman, Brenden, Stefan Hochrainer-Stigler, Luc Feyen, Jeroen C.J.H. Aerts, Reinhard Mechler, W.J. Wouter Botzen, Laurens M. Bouwer, Georg Pflug, Rodrigo Rojas, and Philip Ward. 2014. "Increasing Stress on Disaster-Risk Finance Due to Large Floods." Nature Climate Change 4: 264-68.

Kahl, Colin. 2006. States, Scarcity and Civil Strife in the Developing World. Princeton, NJ. Princeton University Press.

Lipton, Michael. 1977. Why Poor People Stay Poor: A Study of Urban Bias in World Development. London: Australian University Press.

Marchiori, Luca, Jean-François Maystadt, and Ingmar Schumacher. 2012. "The Impact of Weather Anomalies on Migration in Sub-Saharan Africa." Journal of Environmental Economics and Management 63 (3): 355-74.

Marshall, Monty G., and Ted Robert Gurr. 1800-2013. "Polity IV Project: Political Regime Characteristics and Transitions, 1800-2013." Political Instability Task Force, funded by the United States Central Intelligence Agency. https://www.systemicpeace.org/polity/polity4.htm (accessed 11 January 2019).

Miguel, Edward, Shanker Satyanath, and Ernest Sergenti. 2004. "Economic Shocks and Civil Conflict: An Instrumental Variables Approach.” Journal of Political Economy 112 (4): 725-53.

Neuwirth, Robert. 2005. Shadow Cities: A Billion Squatters, A New Urban World. New York: Routledge.

Ostby, Gudrun. 2016. "Rural-Urban Migration, Inequality and Urban Social Disorder: Evidence from African and Asian Cities." Conflict Management and Peace Science 33 (5): 491-515.

Reardon, Thomas, and J. Edward Taylor. 1996. "Agroclimatic Shock, Income Inequality, and Poverty: Evidence from Burkina Faso.” World Development 24 (5): 901-14.

Reuveny, Rafael. 2007. "Climate Change-Induced Migration and Violent Conflict." Political Geography 26 (6): 656-73.

Waldinger, Maria. 2016. "Migration and Climate-Resilient Development." In The Economics of Climate Resilient Development, edited by Sam Fankhauser and Thomas K.J. McDermott. Cheltenham: Edward Elgar.

World Bank. 1901-2016. "Climate Change Knowledge Portal for Development Practitioners and Policy Makers." http://sdwebx.worldbank.org/climateportal/index.cfm?page=downscaled_data_ download\&menu=historical (accessed 7 November 2018). 
United Nations. 1950-2050. "2018 Revision of World Urbanization Prospects." United Nations Department of Economic and Social Affairs/Population Division. https://population.un.org/wup/ (accessed 7 November 2018).

Uppsala Conflict Data Program and Peace Research Institute Oslo. 1946-2008. "UCDP/PRIO Armed Conflict Data Set." Department of Peace and Conflict Research, Uppsala University and the Centre for the Study of Civil Warat the Peace Research Institute Oslo. https://www.prio.org/Data/Armed-Conflict/ (accessed 11 January 2019). 


\section{Climate, Urbanization, and Conflict: The Effects of Weather Shocks and Floods on Urban Social Disorder}

Floods regularly displace large numbers of people in developing countries, leading to increased population movement from rural areas to the largest cities. This paper finds evidence that people's displacement by flooding is associated with a higher risk of social disorder in large cities in developing countries. The evidence suggests that the effects of floods on urban social disorder occur mainly through displaced people being pushed into large cities.

\section{About the Asian Development Bank}

ADB is committed to achieving a prosperous, inclusive, resilient, and sustainable Asia and the Pacific, while sustaining its efforts to eradicate extreme poverty. Established in 1966, it is owned by 68 members -49 from the region. Its main instruments for helping its developing member countries are policy dialogue, loans, equity investments, guarantees, grants, and technical assistance. 